\title{
A CROSS-CUTTING VIEW OF WARSAW INDEPENDENT THEATRE SCENE
}

\author{
ZUZANA TIMČÍKOVÁ \\ Institute of Theatre and Film Research, \\ Art Research Centre of the Slovak Academy of Sciences, Bratislava, Slovakia
}

\begin{abstract}
The study gives a picture of the contemporary independent theatre scene in Warsaw. On a representative sample of four independent theatres (Teatr Polonia, Klub komediowy, Teatr WARSawy, Komuna Warszawa), it illustrates the diversity of the operation and artistic orientation of theatres across an independent, non-institutionalised Warsaw theatre scene. On the basis of certain phenomena which have surfaced in selected theatres when it comes to their dramaturgy and internal organisation, in conclusion, the authoress marginally touches upon the similarities and differences between Polish (Warsaw) and Slovak independent theatre.

Keywords: Teatr Polonia, Klub komediowy, Teatr WARSawy, Komuna Warszawa, independent theatre, Warsaw
\end{abstract}

The incidence of comparable features in the development of non-institutionalised theatre networks in Slovakia and in Poland after 1989 is to be understood as a natural outcome of a similar development of the cultural policies of the two countries known for being former satellite states of the Union of Soviet Socialist Republics. Much like in Slovakia, in Poland, too, a long and complex process of devolution was launched after 1990, seeking an appropriate way of funding public cultural institutions and non-state organisations. From an aesthetics point of view, the origin of noninstitutionalised theatres in Polish theatre culture is closely tied to the artistic legacy of student theatres, small theatre forms or authorial theatres operating prior to 1989 that used to represent the somewhat more experimental and alternative strand of theatre production. According to the Slovak theatrologist Karol Horák, it is the attribute of alternativeness which is among the most frequent general designations of the production of drama ensembles unique by their otherness or unconventional poetics. Horák claims that Polish theatre "continues to be a living example for Slovak alternative theatre. A connecting line between the two cultures is, to say the least, their post-socialist context as well as a number of similar issues in the area in question." ${ }^{1}$

In the Slovak cultural environment, the term independent theatre is used to refer to theatre group which are legislatively placed outside the foundation competence of self-governing bodies, although it does not quite accurately name all the aspects of the operation of such a theatre. Hence, in professional context, the term non-institutionalised theatre is preferred. The term non-institutionalised reflects the fact that the theatre does not have a founder - it exists outside the competence of the State, even outside the regional, municipal or local self-government, it is founded

${ }^{1}$ HORÁK, K. Impulzy, stimuly a modifikátory tvorby divadla alternatívneho typu alebo Alternatívne divadlo na Slovensku po roku 1989 II. In HORÁK, K. - KUŠNíROVÁ, E. - PUKAN, M. (eds.). Kontexty alternatíoneho divadla IV. Prešov : Filozofická fakulta Prešovskej univerzity, 2011, p. 13. 
and ceases to exist independently of the decisions of political structures. However, this does not necessarily mean that it is financially autonomous from State and selfgoverning structures. The concept of independent can be misleading as it creates an impression that the theatre can exist without the financial aid of the State or of the self-government. The current situation in Slovakia indicates that the continuity of the activities of non-institutionalised theatres is tied to the support from public sources, which these theatres receive through grant and subsidy programmes.

Polish terminology uses such terms as independent, alternative, off- or even offrepertory theatres as synonyms, regardless of the type of dramaturgy the theatre offers. $^{2}$ In the theatre infrastructure established in Poland after 1989, the terms public and non-public theatres are also used, ${ }^{3}$ to make a terminological distinction between institutionalised and non-institutionalised theatres.

A group of theatres operating on the basis of private companies with a commercial purpose and a group of theatres referred to as "third-sector theatres" (i.e. theatres of the NGO sector), which were set up as civic associations or non-profit organisations (or, rather foundations), fall into the category of non-public theatres. The Polish theatrologist Paweł Płoski claims that the feature that helps distinguish between the so-called third sector theatres and private theatres is the role they play in the theatre network and vis-à-vis the audience. According to Płoski, private theatres, unlike theatres founded as non-profit organisations or civic associations, are based on profit and commercial purposes.

In actual reality, however, a dividing line defined in this fashion is removed. Part of the selected sample of non-institutionalised theatres in Warsaw indicates that theatres having the legal form of a civic association or of a foundation "behave" more like private theatres and are inclined to develop commercial repertory popular with the audiences. An important aspect that alters the understanding of the dramaturgic orientation of selected theatres and develops their manner of operation in forms unknown in Slovakia, is space, i.e. a place in which theatre professionals permanently operate and stage their performances.

\section{Teatr Polonia, Klub Komediowy - Theatres of Popular Culture}

One the unique theatre formats which has no counterpart in the Slovak theatre context is Krystyna Janda Foundation (Fundacja Krystyny Jandy na Rzecz Kultury). ${ }^{4}$ It is a family business/organisation founded in 2004 on the initiative of the popular

\footnotetext{
${ }^{2}$ Off-theatre is a concept based on the naming of a movement of small theatres that were started in New York in the 1940s and 1950s, as a reaction to Broadway theatre scene, and were referred to as off-Broadway theatres. Off-Broadway movement is considered an alternative to Broadway commercialism and diversification of the then New York theatre. Off-Broadway theatres were smaller theatres managed by less-acclaimed directors. They were noted for a more experimental theatre production and inventive staging methods, thus responding to the crisis of the big Broadway theatre. Among the best-known Off-Broadway theatres was The Living Theater. For more see BROCKETT G, O. Dějiny divadla. Praha : Nakladatelství Lidové noviny, 1999, pp. $333-334$.

${ }_{3}^{3}$ PŁOSKI, P. Theatre Organisation System in Poland. In Polish Theatre Journal, 1-2(3-4)/2017. [online]. [cit. 28 April 2020]. Available at: https://www.polishtheatrejournal.com/index.php/ptj/article/view/118/595.

${ }^{4}$ The term "fundacja" literally means "foundation". However, it is not what a Slovak would understand to be an organisation with a specific purpose to pool assets and manage a fund. Semantically, it is more an equivalent of a non-profit organisation.
} 
Polish actress Krystyna Janda, her husband Edward Kłosiński, and of her daughter Maria Seweryn who is also an actress. The foundation is a legal entity, acting as an umbrella for two theatres: Teatr Polonia (Theatre Polonia) and Och-teatr (Och-Theatre). Although the theatres as the organisational units of Krystyna Janda Foundation fall under the NGO sector, their theatre production is of a semi-commercial nature.

Krystyna Janda's original vision of founding her own theatre was only associated with Teatr Polonia. The theatre mounted plays on a small stage as early as 2005. It was a smaller studio space, which was extended by a larger theatre hall and an auditorium with a larger spectator capacity later on. While at the outset, the dramaturgy of the small studio stage was strictly focused on women's themes that were captured using the means typical of small theatre forms, the gradual expansion of space resulted in a natural change of the theatre's dramaturgical needs with respect to its viewer.

The initial inclination toward feminist production was also declared by the theatre naming its small theatre space as Fiolotowe Pończochy (Violet Stockings). ${ }^{5}$ The first 2005/2006 theatre season was marked by the creation of female playwrights who gave an account of the status of woman and of her feeling of life in "New Europe" on the verge of the $20^{\text {th }}$ and $21^{\text {st }}$ centuries. ${ }^{6}$ In a number of interviews, Krystyna Janda reminisces that her themes primarily draw from Balkan and Ukrainian literature, reflecting on the life style of an emancipated woman aged thirty to forty. During the first theatre season, the small stage of Teatr Polonia mounted the drama adaptation of the short story Stefcia Ćwiek w szponach zycia [Steffie Speck in the Jaws of Life] by the Croatian authoress Dubravka Ugrešić; a monodrama based on the text by the Croatian journalist and novelist Vedrana Rudan Ucho, gardlo, nóz [Ear, Throat, Knife] casting Krystyna Janda; a monodrama based on the text by the Ukrainian authoress Oksana Zabuzko Badania Terenowe nad ukrainskym seksem [Field Work on Ukrainian Sex]; and a production based on the novel Darkroom by the Croatian authoress Rujana Jeger. All productions have portrayed a woman's perception of the world. The issue was thematised in a variety of contexts, for instance, looking for a partner or a change in the beliefs, values, and attitudes of a woman who survived the Balkan war.

However, expanding to other spaces (opening the big stage of Teatr Polonia in 2006 and the opening of Och-teatr in 2010) led to a programmatic and dramaturgical branching of both theatres towards commercial formats. Och-teatr as another organisational unit of Krystyna Janda Foundation has an artistic offer closer to that of the centre of culture and entertainment. The programme of Och-teatr is more multi-genre and, in addition to theatre productions, it offers a range of non-theatre activities, from educational formats to concerts and other musical events. The theatre programme section consists mainly of lighter comedy titles of contemporary domestic and world playwrights. Overall, the offer of Och-teatr is structured to accommodate the taste of the audience when it comes to forms and themes, by which the organisers bet on the certainty of profit. Commerciality also gets a place in the repertory of Teatr Polonia. Compared to Och-teatr, however, it approaches dramaturgy in a more diverse way and also stages productions for a more discriminating viewer. Small stage

\footnotetext{
${ }^{5}$ The title Violet Stockings was borrowed from a $19^{\text {th }}$ century French feminist movement. For more go to CZAPSA, N. Upadłe kino w fiolecie pończoch. In Žycie Warszawy, 2005, Vol. 62, Issue 252.

${ }^{6}$ GŁOWACKA, I. Nie tylko babskie gadanie. Teatr stawia na kobiety - bawi je i zmusza do refleksji. In Metropol - Warszawa, 2005, Vol. 6, Issue 207.
} 


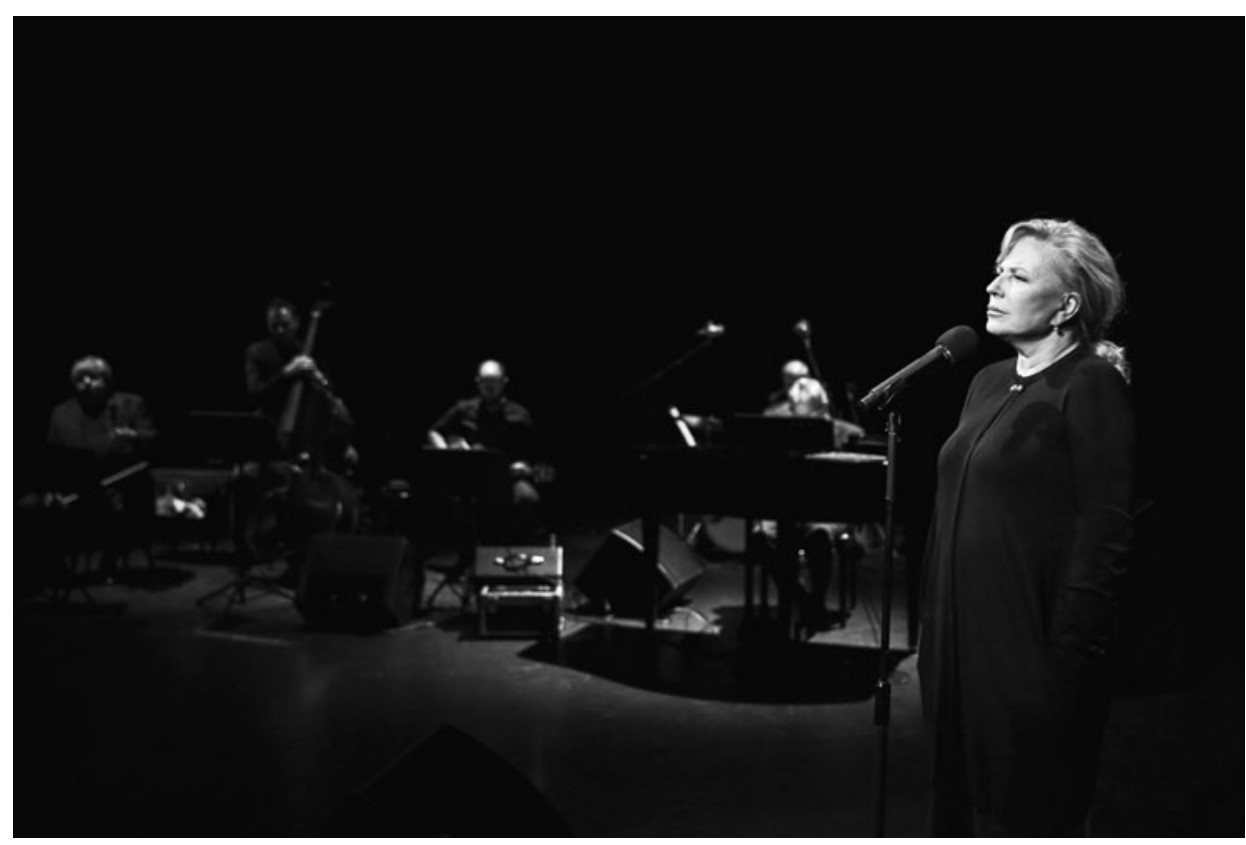

Sabina Baral: Zapisky z wygnania (Notes from Exile). From left orchestra members under the baton of Janusz Bogacki and Krystyna Janda. Polonia Theatre, Warsaw, premiered on 9 March 2018. Direction Magda Umer, conductor Janusz Bogacki. Photo by Katarzyna Kural-Sadowska. Polonia Theatre archives.

forms, musical-poetic recitals and a line of monodramas dedicated to the reflection of women's views on the modern world or the staging of texts by female authors are still an important part of Teatr Polonia. Among them is, for instance, monodrama by Krystyna Janda Zapisky z wygnania [Notes from Exile], based on the recollections of a Jewish woman Sabina Baral, who had to forcibly emigrate from Poland in 1968. The documentary theme is adapted as an intimate personal narrative of Janda, accompanied by her singing and live music.

According to the theatre critic Marta Cabianka, Teatr Polonia proved to be successful with both the spectators and critics in just a short period of time. Back in 2006, Cabianka described the work of Teatr Polonia as "liberal, intelligent, elaborate, while giving the audiences what they want". ${ }^{7}$ In her understanding, the theatre opened up to new streams and intellectual stimuli and brought "an educational, understandable, social, not overly intellectual, innovative, but not avant-garde, courageous, but not aggressive repertory". ${ }^{8}$ In turn, theatrologist Artur Klus looks at the artistic direction of the theatre through the lens of a theory of postmodern culture. According to him, Teatr Polonia is positioned on the border line between the other two types of theatres, i.e. commercial and experimental which prioritises quality over profit. ${ }^{9}$

\footnotetext{
${ }^{7}$ CABIANKA, M. Teatr Polonia: Pól kroku przed widzem. In Dialog, 2006, Vol. 51, Issue 10, p. 42.

${ }^{8}$ Ibid., p. 43.

${ }^{9}$ KŁUS, A. Lider $w$ Kulturze. Studium działalności Krystyny Jandy. Warszawa : Mazowieckie centrum Kultury i Sztuki, 2011, pp. $42-43$.
} 
Today, Teatr Polonia and Och-teatr are active repertory theatres that perform almost on a daily basis, even during the summer theatre holidays. This way of operation naturally brings titles attractive to viewers that make profit. The structure of Teatr Polonia, its staffing, profit-oriented operation, the frequency of introducing new titles as well as their retention in the repertory over an extended period of time clearly show that the theatre has distanced itself from an operation typical of noninstitutionalised theatres. Both organisational units of Krystyna Janda Foundation, Teatr Polonia and Och-teatr, are highly profitable private theatres. ${ }^{10}$

An example of a commercial theatre having legal personality of a civic association (stowarzyszenie) is the well-known and popular theatre club Klub Komediowy (Comedy Club) in Warsaw. In a way, it is ironical that a civic association is connected with a private theatre whose repertory consists of titles that are attractive to viewers. Its stakeholders also invest in other independent business entities (bars and clubs) for the sake of profit. In parallel, Klub Komediowy is a good example of how an intensive care for the operated space can turn a small independent theatre ensemble into an entertaining-popular club. The roots of Klub Komediowy go back to an independent group of the improvised Klancyk theatre which was founded in 2005. The origin of the Klancyk formation dates back to the student times of its individual members. Initially, it was a group of seven people, without a permanent space, who performed in clubs, art cafeterias and later in the cultural centre Chłodna 25 which is no longer in existence. Michal Sufin, the leading personality of Klancyk ensemble, together with other partners, after having worked outside permanent theatre scene, started Klub Komediowy as a multi-programme platform for improvised theatre - comedy genres of small stage and cabaret forms and stand-up theatre.

Maintaining the space and its profitability necessitated the expansion of the repertory, to retain the maximum possible interest of its audiences. Of the selected sample of non-institutional theatres, Klub Komediowy does not apply for public funding from the grant schemes of the ministry of culture or from the City of Warsaw. The funding of the theatre club is based on the profit from its own productions and the operation of a bar. Klub Komediowy organizes a wide range of profit-generating non-artistic activities in its venue (e.g. marketing and business events), it also works for the creative industries (e.g. screenwriting), etc.

The club's dramaturgical profile overlaps with the search for the most viable paths to financial security outside the grant policy. During the first two years of its existence, the club operated mainly as a production house, in which the organisers provided space to several comedy-oriented theatre ensembles. The profit from performances went to performing troupes. After two years of operation, however, Klub Komediowy ended up in debt. This made its representatives focus on their own productions while creating other commercial formats to cover costs. Michał Sufin argues that independence from public funding leads to a dependence on audience's preferences, demand, and interest. ${ }^{11}$

${ }^{10}$ Teatr Polonia and Och-teatr are based in former cinema premises and their conversion was partly financed by the founder from her own resources and from the sale of her house. The conversion was primarily funded from EU grant programmes.

${ }^{11}$ Restatement is based on a personal interview given to the authoress by M. Sufin, Warsaw, 23 October 2019. 


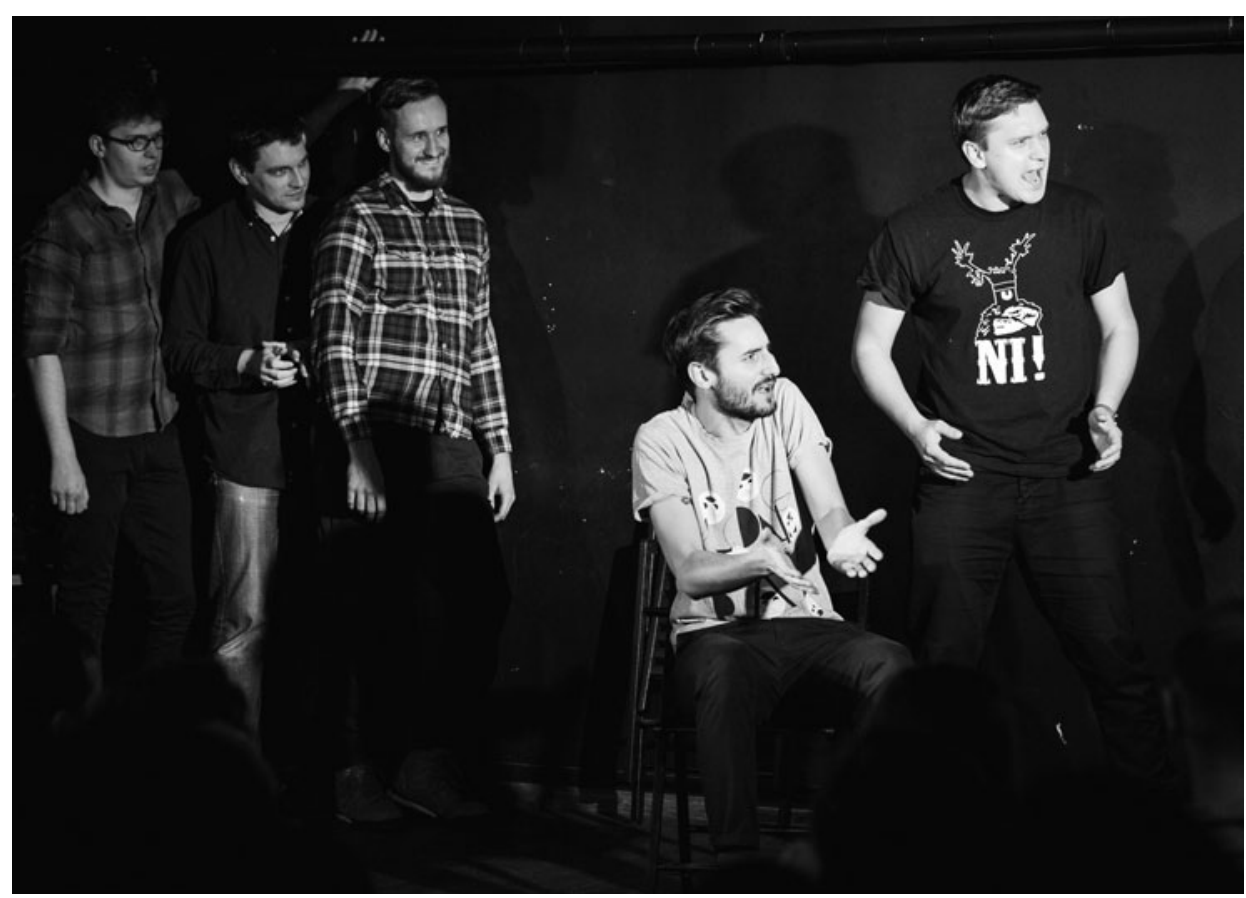

Klancyk, improvisational theatre group: Zaburzone osobowości (Disturbed Persons). From left Krzysztof Dziubak, Krzysztof Wiśniewski, Paweł Najgebauer, Maciej Buchwald, Bartosz Młynarski. Klub Komediowy (Comedy Club in Warsaw), premiered on 29 April 2010. Photo by Andrzej Stawiński. Klub Komediowy archives.

Improvised performances of Klancyk ensemble are still a regular part of the programme of Klub Komediowy, but overall, the repertory also consists of other authorial productions by creative professionals who are part of the club's artistic team. Klancyk gives performances in the club every Friday evening and at night, for three consecutive times. Its repertory builds on well-established thematic areas that facilitate the development of improvised scenes. For example, Zaburzone osobowości [Disturbed Persons] series is popular with the audience. At the beginning of each performance, the actors briefly introduce themselves in fictional characters. The audience then decides which of the presented characters will become the main hero of the story whom the actors further develop in improvised performances.

\section{Komuna Warszawa and Teatr WARSawy - Residence Centre and Repertory Theatre}

A counterpart to popular entertainment theatres is, for example, Komuna Warszawa. Unlike the above-mentioned examples, it does not build a repertory composed of commercial titles attractive to the audience, but rather offers space for a theatre experiment. On the one hand, it operates as a theatre with authorial creation, on the other, it is a residential centre and a production house. The current format of Komuna Warszawa is an outcome of an artistic evolution of a close community of individu- 
als who embarked on their activities in 1989 under the name Komuna Otwock. ${ }^{12}$ It was a student engaged, anarchist even, movement, whose inception was impacted by the then political situation in Poland. It did not focus on continuous production activity, but rather carried out various performative activities and interventions in public space, such as writing revolutionary manifestos, distributing promotional leaflets with anarchist slogans, splashing colours on buildings in the city centre or creating random installations from garbage. The early activities of Komuna Otwock were more of a political-civic gesture, a radical expression of the social attitudes of a counter-cultural movement, manifesting the actors' discontent with the political and social state of the country. Alina Gałazka, one of the founding members of Komuna Warszawa, former performer and currently, theatre project manager, emphasizes the line of subjective motivations associated with adolescence and the ageing of the group members in the transformation of Komuna Otwock from a counter-cultural movement to a theatre. The vision to professionalise theatre production and its organisation went hand in hand with the personal need to stabilise the professional and creative life of individuals. ${ }^{13}$

Komuna Warszawa moved to the space where it currently operates back in 2006. Over the years, three basic strands have developed in its programme and dramaturgical orientation, i.e. own staging activity, production and residential activities, and guest performances of foreign ensembles. Ironically, own creation within the meaning of the continuity of a politically engaged gesture and intervention activities is almost nil. Grzegorz Laszuk, artistic director and the leading personality of Komuna Warszawa, informally called "the father of Komuna"14 is the director of most of these projects. The year-round programme is dominated by the theatre projects by external theatre professionals, with Komuna Warszawa comprehensively covering the production and the outputs of artists-in-residence programmes. The development of these activities that constitute the theatre's repertory is approached by theatre professionals in a highly conceptual fashion. When projects are developed, guest artists work within defined thematic, and partly aesthetic, frameworks. These are not oneoff projects, outputs from residencies (although not all) and productions by external theatre professionals remain in the theatre's repertory and are regularly staged. As an example, let us mention productions that were staged within the thematic cycle Przed wojna/wojnalpo wojnie [Before the War/War/After the War). Since 2017, in each season, guest directors have prepared three productions, repeatedly staged as part of the theatre's programme. It was not a reflection on war in the meaning of its understanding as a (concrete) armed conflict. The defined thematic framework provided the theatre professionals with a space to contemplate war as a conflict in the context of psychology, personal or family crises, but also in the primary historical and political context.

${ }^{12}$ The name Komuna Warszawa was adopted in 2009. The name Komuna Otwock was derived from the name of a smaller Polish town (with a population of some 45,000), where it had operated until 2007 before moving to Warsaw.

${ }^{13}$ Restatement is based on a personal interview given by A. Gałazka to the authoress. Warsaw, 25 October 2019

${ }^{14}$ Unlike the productions of other directors, there is a minimum of productions under his direction listed in the current programme offer. For example, in 2019, only one production of a total of eight new ones was put on stage in collaboration with Grzegorz Laszuk and female director Weronika Szczawinska. 
The diversity of staging approaches to a given ideological concept is best seen from an example of two productions mounted in the 2019 residence cycle. The music and theatre project Wojna. The best of [War. The best of] directed by Agnieszka Jakimiak was developed as a concert in which the musical performances of four performing actors alternated with spoken parts. The actors acted as moderators on the radio. They discussed the (in)significance and futility of military conflicts, while famous war songs were played at the audience's request, which they then performed on stage. The production Dobrze ci tego nie opowiem [I Cannot Tell You Well], directed by Anna Karasińska, worked with an empty, minimalist scenic space. She focused on the actor, his/her work with the body and narration. There were four actors taking turns on the stage, each interpreting his/her understanding of war through specifically chosen means. Each actor's narrative was portrayed, for example, through a civil narration of a family story or a movement accompanied by a minimalist verbal expression. This created a line of four different narratives about the war, with intermingling short stories of the crisis of identity, family disputes, and of human survival during the war.

The residencies in Komuna Warszawa are also characterised by unique thematic areas. The annual residency cycle takes place under the guidance of a curator - director appointed in advance and it generates five staging (i.e. residential) outputs. Let us mention, for example, the 2019 residency programme, whose determining theme was Krajoobraz [Landscape]. Under the curatorial direction of director Weronika Szczawińska, ${ }^{15}$ a group of interdisciplinary projects transcending the boundaries of performative arts was set up. An example of this residency cycle is given to illustrate that one of its outputs, the dance-light performance Rodos - Rodzinne Ogródki Dziatkowe Ogrodzone Siatka [Rodos-Fenced-In Family Allotment Gardens] directed by Wojciech Grudzinski, has been included in Komuna programme. The regular staging of the production Rodos thus confirms that projects developed under the residence programmes in Komuna Warszawa are sometimes retained in the theatre's repertory. ${ }^{16}$

In connection with all implemented projects, Komuna Warszawa is considered a laboratory, an experimental theatre, representing post-dramatic forms, a theatre that has the potential to constantly generate inventive formats. For example, one of the long-term experimental projects appreciated by Polish theatre critics was the socalled Micro theatre format. The project was primarily intended for theatre professionals who have not yet established themselves on the theatre stage. Under the conditions following the strictly defined possibilities of stage equipment and scenery, or their limitations, selected artists were asked to create 16-minute performances, with not more than four actors performing. They had four spotlights, two microphones, one projector and one arbitrarily selected prop. The concept of Micro theatre was understood as a self-reflection project of Komuna, drawing attention to the situation

${ }^{15}$ Weronika Szczawińska has staged several projects as a guest director at Komuna Warszawa. In 2018, she took part in the aforementioned cycle Before the War/War/After the War and also put on stage Nigdy wiecej wojny [Never Again War], which thematised World War II through the personal memories of survivors.

${ }^{16}$ The production is detailed by theatre critic Kacper Ziemba. See ZIEMBA, K. Rozejrzyj się. In Teatralia, 21 October 2019. [online]. [cit. 10 May 2020]. Available at: https://www.teatralia.com.pl/rozejrzyj-sie/. 


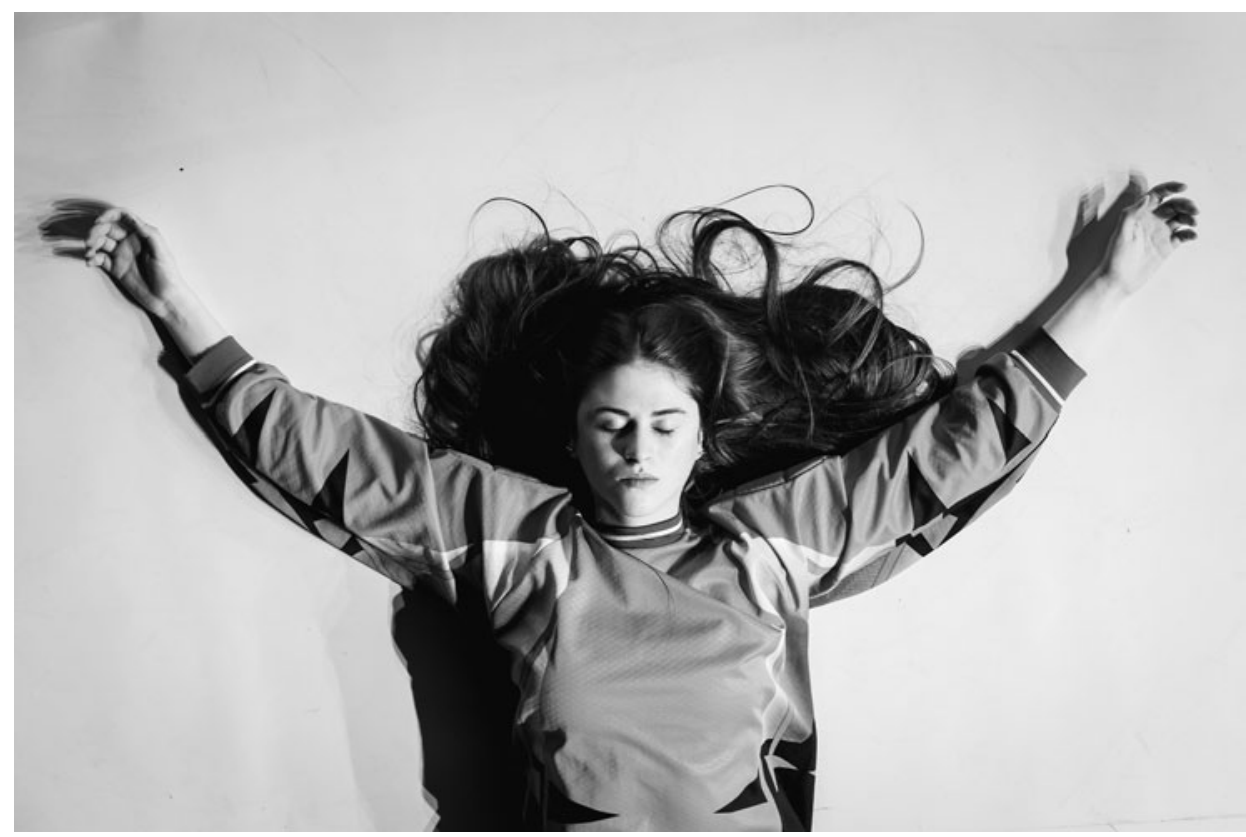

Anna Karasińska: Dobrze ci tego nie opowiem (I Cannot Tell You Well). Bożena Wydrowska. Komuna Warszawa, premiered on 8 September 2019. Direction Anna Karasińska. Photo by Pat Mic. Komuna Warszawa archives.

and the manner of creation of independent artists struggling with limited funding. Among its aims was to encourage the artists taking part in projects in stirring up a discussion on the current theatre system. ${ }^{17}$

Komuna Warszawa, more than being a theatre within the meaning of profiling and developing its own distinctive poetics, has thus evolved into a platform facilitating the implementation of experimental and innovative theatre projects and into a production and residential centre. The original group of leading personalities connected with the theatre (or, rather, a community of activists) at its early stage, such as Gregorz Laszuk and Alina Galazka, shifted from its initial position of performers into organisational and administrative spheres of the theatre. On the other hand, although Komuna Warzsawa is not an authorial theatre whose staging signature style would be recognized by the creation of one or two leading personalities, it has managed to maintain the seal of its one-time uniqueness and the reputation of a politically engaged theatre also thanks to a range of guest projects included in its repertory.

\footnotetext{
${ }^{17}$ Organisers claim they took the inspiration to launch the projects in "Micro theatre" format from TEDex presentations, Dogma 95 manifesto, and from the activities of other foreign experimental ensembles and theatre professionals (OuLiPo, the activity of Tim Etschells, Tino Sehgal or Jérôme Bel). For more see CIELATKOWSKA, Z. Mikro Teatr. Minimalna przestrzeń śmiechu. In Dialog, 2017, Vol. 62, Issue 3, p. 188.
} 


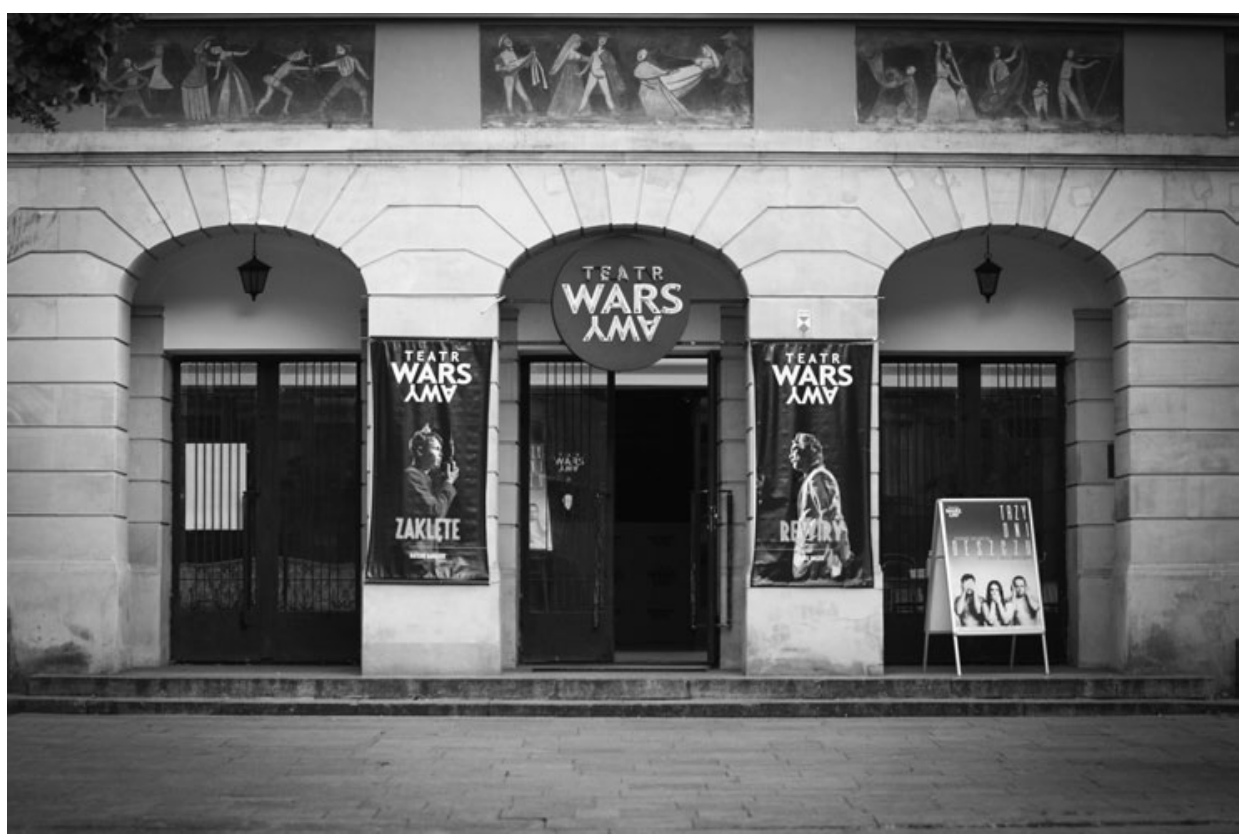

The former WARS cinema building currently housing Teatr WARSawy (WARSawy Theatre). Photo by Przemysław Wojtaś. Teatr WARSawy archives.

Teatr WARSawy (WARSawy Theatre) ${ }^{18}$ is another theatre managing theatre activities in a permanent space. It has been profiled in a similar way, although it lacked stronger ambitions to experiment and opted for a more conventional production. Under the original name Teatr Konsekwentny (Konsekwentny Theatre), it began operating as an independent semi-professional grouping of young theatre professionals as early as 1997. Its leading personality was Adam Sajnuk who is still artistic director and leader of Teatr WARSawy, director and person shaping the theatre's dramaturgical concept. Over the years, the theatre has become more professional, whereby a significant part of its evolution has been marked by a lengthy search for a suitable space which has been accompanied by many ups and downs and constant moving to new spaces. ${ }^{19}$ An intensive search for theatre space began after 2010. It was the relocation of the theatre to the building of the former WARS cinema that posed new challenges to the theatre, especially when it comes to finding dramaturgical balance. Adam Saj-

${ }^{18}$ The current name Teatr WARSawy is connected with its seat which has been the building of former WARS cinema since 2013. Its original name was Teatr Konsekwentny. The name of the civic association under which the theatre operates is the Civic Association of Konsekwentny Theatre.

${ }^{19}$ An aspiration to find a stable venue was at its climax roughly two years before it had finally moved into the building that used to house WARS cinema. Until 2011, the theatre (known as Teatr Konsekwentny) had been housed in the premises of Stara Prochovnia cultural centre. After the lease contract was terminated, the theatre temporarily moved to a complex of buildings of a one-time vodka distillery known as Koneser. The premises of Koneser that housed Teatr Konsekwentny since 2011 were in disrepair and theatre professionals were unable to guarantee adequate conditions for its continuous production. The search for a more suitable space continued and currently, the entire venue has been reconstructed and converted into a cultural-creative and a shopping centre. 


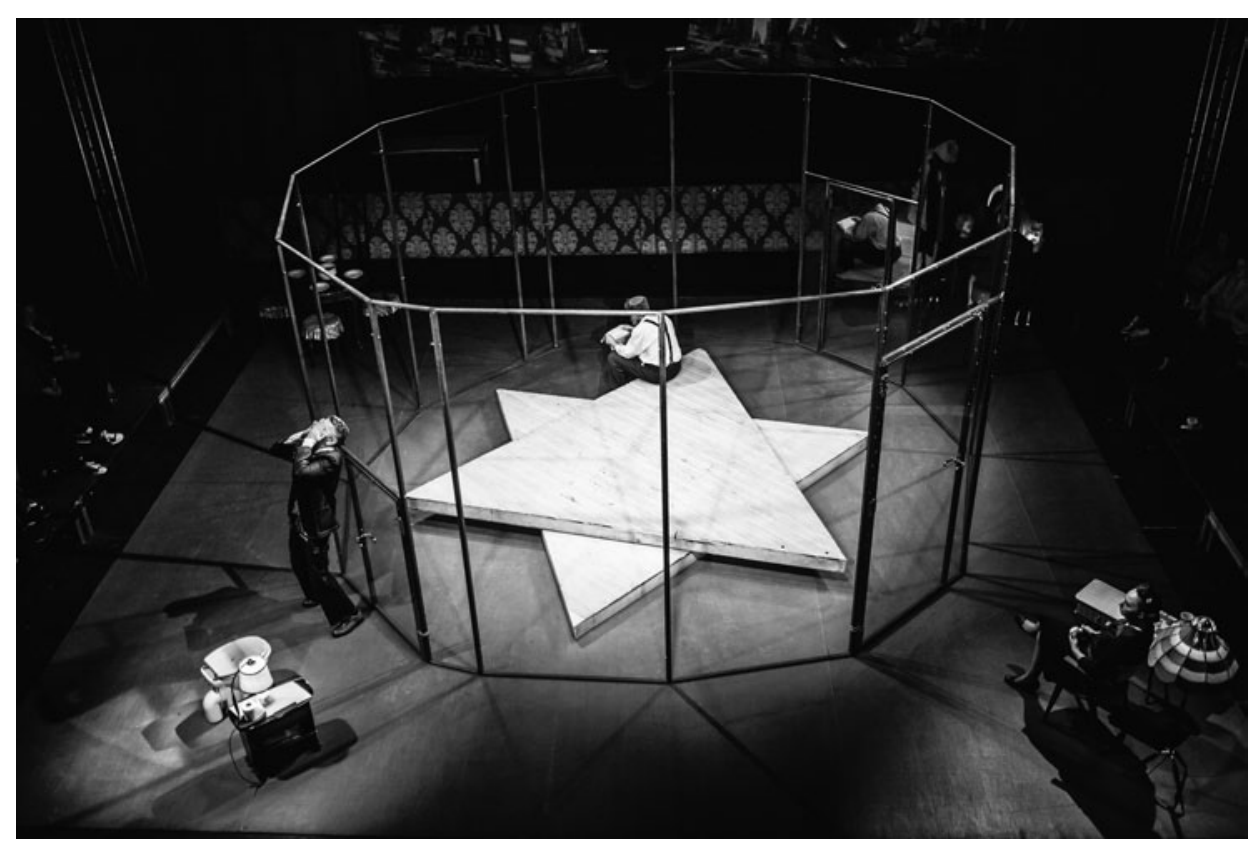

Philip Roth: Kompleks Portnoya (Portnoy's Complaint). From left Adam Sajnuk (Alex Portnoy), Bartosz Adamczyk (Father), Monika Mariotti (Mother). Teatr Konsekwentny (Konsekwentny Theatre in Warsaw - currently operating as WARSawy Theatre), premiered on 27 May 2010. Direction Adam Sajnuk, Aleksandra Popławska. Photo by Rafał Meszka. WARSawy Theatre archives (former Konsekwentny Theatre).

nuk has always seen a close connection between the theatre's ambitions and its stable existence in a single space (building) and aspired to set up "off repertory" theatre that would compete with the repertory of institutionalised theatres.

The current mode of operation of Teatr WARSawy and the staging of performances in one part suggests the model of a repertory theatre, in other part, a cultural and community centre, or rather, a platform facilitating the establishment of young and beginning theatre professionals. The programme presented by the theatre displays deliberate diversity of genres and themes. Among the staged titles are classical drama, musical and dramatic performances and even stand-up comedy. Teatr WARSawy does not have a permanent drama ensemble or dramaturg-director duo. Its productions are an outcome of projects and endeavours of various groups of creative professionals who are invited to collaborate with Teatr WARSawy. The theatre gives space to authorial theatre but also to theatre that is created conventionally on the basis of a pre-existing drama text. The theatre's programme thus contains productions created under Teatr WARSawy brand (most often directed by Sajnuk), performances by guest independent theatre ensembles without a permanent space, and theatre performances of Spoleczna scena debutów (A Stage for Beginners) project. The primary focus of the project designed for students and fresh graduates of drama art is to promote the connections between students or fresh graduates and well-established directors, to work together on a production during a project. Even though it is an extra activity of the theatre, as organisers would claim, the project outputs constitute the core of 
its year-round activity. For example, in 2018/2019 theatre season, the staging outputs from this project were the only new productions of the theatre. ${ }^{20}$

\section{On Several Polish/Warsaw-Slovak Similarities and Differences}

It comes naturally that permanent space requires a new organisational structure and new needs crop up with respect to the funding of its day-to-day operation (overheads, possible refurbishment), which, logically, interferes with programme design and an overall staging activity. The above examples from the Warsaw's theatre scene demonstrate that if the theatre professionals' ambition was to fill the space with theatre performances and retain their audiences, they had to come up with a more diverse repertory, including commercially successful pieces and opt for a more institutionalised way of operation. Thus, the specific nature of the methods applied and a unique poetics, which is a fundamental feature of independent theatre, as interpreted by theatrological discourse in Slovakia, has been lost.

Theatre practitioners and organisers of some theatres (e.g. the aforementioned Teatr WARSawy) approach the notion of independence (or rather otherness compared to institutionalised theatre) through the organisational side of the theatre. They define independence through the setting up of employment relationships (theatre professionals do not have permanent employment relationships with the theatre but rather concluded contracts for works) or through a non-hierarchical staff structure. None of the abovementioned theatres has a permanent artistic ensemble, nor a permanent core having the form of a dramaturg-director or actor-director duo, which we find in independent theatres in Slovakia. Marta Bartkowska, former PR manager of Teatr Polonia and assistant to Krystyna Janda, in an interview with Bartłomiej Miernik and Paweł Płoski for Teatr magazine, emphasises that the essence of artistic freedom and independence is the non-attachment of individual creative professionals to the theatre through permanent employment contracts. ${ }^{21}$ The presented examples of private or independent theatres, which are conceived as platforms for the presentation of works by other theatre professionals, subsequently eliminate the possibilities of a continuous development of the original founders' own production. It is therefore more exacting to have to deliberate the specificities of the poetics of an independent theatre in question. Productions are not an outcome of continuous creation of "in-house" directors, but rather a product of the work of changing creative teams which come to work together with the theatre. The phenomenon of an inseparable bond between the founding personalities and the existence of a theatre is being increasingly shifted from an artistic domain to an organisational domain. For instance, Adam Sajnuk, the founder of Teatr WARSawy, is currently both its artistic and project manager, Grzegorz Laszuk, the founder of Komuna Warszawa, is its director, and former actress Alina Gałazka is its project manager. They all maintain contact with the theatre's production activity (Krystyna Janda has an input in some productions as director and actress, Grzegorz Laszuk as founder and director of Ko-

\footnotetext{
${ }^{20}$ In the theatre season, three titles were premiered in May, followed by three more premieres in June, which were the mandatory outputs of Spoleczna scena debutów project. This included two musical productions, two stand-up and two drama productions.

${ }^{21}$ MIERNIK, B. - PŁOSKI, P. Poczucie bezpieczeństwa. In Teatr, 2008, Vol. 63, Issue 3, pp. 49 - 50.
} 
muna Warszawa is still director or curator of artists-in-residence programmes, and Adam Sajnuk is still director at Teatr WARSawy), however, the image of their poetics is not primarily legible through their artistic contributions. On the other hand, in the Slovak context, it is characteristic that it is the founders of independent theatres who continue to significantly determine and profile the artistic image of these theatres. With artistic growth and the changing life attitudes of theatre professionals, staging methods, themes, and poetics continue to change and develop. Authorship is strongly connected with both creation and the operation of these theatres, and as theatre professionals leave, the theatre ceases to exist.

Examples from the Warsaw theatre scene indicate that working in permanent spaces naturally raises the need for developing a regular programme offer. Therefore, it is common to refer to some theatres as repertory theatres. The model of an established repertory theatre does no longer stand in opposition to independent theatre. On the contrary, independent theatre converges on it, it becomes institutionalised. By contrast, in Slovakia this designation continues to be in semantic and terminological opposition to the notion of independent theatre. In Slovakia, too, independent theatres develop their repertories through continuous activities, but since most of them do not have permanent premises, they are not subject to the necessity to develop a permanent programme offer. Theatres that operate in permanent spaces complement the regular programme with other artistic and non-artistic activities (for example, by various educational projects) and profile themselves as multi-genre cultural centres.

The above shortlisted examples from Warsaw indicate that a different approach to creating programme activities in a permanent space results in the diversity of the "models" of independent, i.e. non-public theatres. Hence, a wide range of theatres or theatre centres is being established, which vary by their artistic and non-artistic activities and this leads to ambiguous terminology. The organisational side of the theatre predetermines aesthetic and thematic frameworks of creation, meaning that theatres shift from popular to entertaining forms (Teatr Polonia, Klub Komediowy), from production houses (Komuna Warszawa) to theatre fora that promote young theatre professionals who have not yet established themselves (Teatr WARSawy).

A characteristic feature of the production of independent theatres is the diversity of drama poetics which is shaped by the specific circumstances under which theatres operate. Therefore, the artistic development of these theatres cannot be separated from non-artistic, i.e. organisational activities. The fact whether a theatre operates in a permanent space or not is among the determining factors of the organisational and operational aspects of the theatre affecting its creation and artistic profiling. The search for spatial stability is among the essential challenges facing the majority of independent theatres in Slovakia. A theatre's ambition to operate in a permanent space raises questions concerning its staffing and economic thriving, as well as adequate programme achievement. The path to stabilisation naturally conditions the artistic direction of theatres, which must find new dramaturgical starting points in their own spaces.

The study is an output of the project VEGA 2/0110/19 Poetics of Contemporary Performance Art.

Translated by Mária Švecová 


\title{
LITERATURE
}

BROCKETT, Oscar Gross. Dějiny divadla. Praha : Nakladatelství Lidové noviny, 1999. 948 p. ISBN 80-7106-364-9.

CABIANKA, Marta. Teatr Polonia: Pól kroku przed widzem. In Dialog, 2006, Vol. 51, Issue 10, pp. 42 - 45. ISSN 0012-2041.

CIELATKOWSKA, Zofia. Mikro Teatr. Minimalna przestrzeń śmiechu. In Dialog, 2017, Vol. 62, Issue 3, pp. 184 - 197. ISSN 0867-4051.

CZAPSA, Iza Natasza. Upadłe kino w fiolecie pończoch. In Žycie Warszawy, 2005, Vol. 62, Issue 252. ISSN 0137-9445.

GŁOWACKA, Iza. Nie tylko babskie gadanie. Teatr stawia na kobiety - bawi je i zmusza do refleksji. In Metropol - Warszawa, 2005, Vol. 6, Issue 207. ISSN 1641-3539.

HORÁK, Karol - KUŠNÍROVÁ, Eva - PUKAN, Miron (eds.). Kontexty alternatívneho divadla IV. Prešov : Filozofická fakulta Prešovskej univerzity, 2011, 321 p. ISBN 978-80-555-0464-3.

KŁUS, Artur. Lider w Kulturze. Studium działalności Krystyny Jandy. Warszawa : Mazowieckie centrum Kultury i Sztuki, 2011. 209 p. ISBN 978-83-60623-89-3.

MIERNIK, Bartołomiej - PŁOSKI, Paweł. Poczucie bezpieczeństwa. In Teatr, 2008, Vol. 63, Issue 3, p. 49 - 52. ISSN 0040-0769.

PŁOSKI, Paweł. Theatre Organisation system in Poland. In Polish Theatre Journal, 1-2 (3-4)/2017. [online]. [cit. 28 April 2020]. Available at: https://www.polishtheatrejournal.com/index.php/ ptj/article/view/118/595. ISSN 2451-2966.

ZIEMBA, Kacper. Rozejrzyj się. In Teatralia, 21 October 2019. [online]. [cit. 10 May 2020]. Available at: https://www.teatralia.com.pl/rozejrzyj-sie/. ISSN 1689-6696.

\author{
Zuzana Timčíková \\ Ústav divadelnej a filmovej vedy CVU SAV \\ Dúbravská cesta 9 \\ 84101 Bratislava \\ Slovakia \\ e-mail: zuzana.timcikova@savba.sk
}

